In this way the case goes on from week to week, the plate being gradually shortened as the hoof grows down, until at last it can be completely left off.

The advantages of this method of treatment over the old system hardly need pointing out, the great gain being that, though we treat the wall by radical excision, yet the horse need not be laid up for a single day.

I treat toe sand-cracks and defects in the wall of the hoof caused by injuries to the coronet in a similar manner. The plate in this case is about one and a half inches wide, and as long as desired; four or five holes are placed on either side, and the plate screwed to the wall. The crack grows down sound and the horse does not go lame again from this cause.

A few years ago I stated that there was a great future in store for the mechanical treatment of diseased feet; every day proves the correctness of this statement, and the simple procedure just described is a small but important addition to the list.

In my next communication I will describe the method of converting a shrivelled up and contracted foot into one of normal shape and proportions.

\title{
AMERICAN PLEURO-PNEUMONIA.
}

\section{By Thomas Waller, M.R.C.V.S., Principal, Royal Vetcrinary College, Edinburgh.}

SEEING that I have been so often quoted in connection with the above subject during the past few months, I deem it a duty to myself to pen a few remarks thereanent.

Professor Williams appears to lay claim to the possession of a more intimate knowledge on the subject of pleuro-pneumonia than that possessed by his confrêres, but this claim is greatly weakened by the fact that he has on different occasions held or expressed very different opinions on the subject.

This controversy is not of to-day only; it originated coincidently with the declaration of the existence of pleuro-pneumonia in the cargo of the s.s. "Ontario" by the officers of the then Privy Council at Liverpool, and it is curious that Professor Williams then took up exactly the same ground he has taken up on the present occasion, but he required a space of considerably more than 24 hours to enable him to arrive at a decision.

In reference to Professor Williams's consistency, I shall direct attention to one or two incidents of the past, the accuracy of which I challenge him to deny.

A number of years since, during the course of a celebrated trial, Professor Williams declared on oath in a court of law that an animal had suffered from pleuro-pneumonia two or three months before the date of slaughter, and that the proof of this was the existence of a patch of new interstitial tissue attaching the costal to the pulmonary pleura on one side of the chest.

On another occasion, Professor Williams declared, also in a court of law, that the post-mortem examination of the lungs of an ox or cow 
was insufficient to differentiate between sporadic and epizootic pleuropneumonia.

The mind of Professor Williams has passed through various phases since he made the above statement, as witness the ideas promulgated by him at a meeting of the Scottish Metropolitan Association held at Perth some time ago, and his present attitude as to the value of microscopy in determining the differential characteristics of the two forms of pneumonia.

I have always contended that an absolute rule cannot be laid down in reference to the situation of the initial lesion of pleuro-pneumonia, which does not follow the course of any ordinary or recognised type of pneumonia; and further, I have always pointed out the great importance of differentiating between accessory lesions and concurrent lesions of accidental origin. The necessity of doing this must have been strikingly brought home to the mind of Professor Williams on an occasion when he gave to one person a certificate to the effect that a certain section of lung submitted to him for examination was the subject of broncho-pneumonia, and several days subsequently granted to another person a certificate to the effect that the same lung was the subject of pleuro-pneumonia.

In the course of the discussion a passage has been quoted from an editorial in the Veterinary Joumal in reference to the outbreak of the disease in American cattle in I879. As I pointed out at a recent meeting of the British Dairy Farmers' Association, the article in question was grossly inaccurate as to facts, it being therein stated that large numbers of animals had been slaughtered at our ports because one or two cases of pleuro-pneumonia or supposed pleuro-pneumonia had been found in a cargo of American cattle, whereas it is well known that subsequent to the condemnation of the cattle at Liverpool in I879 thousands of animals affected with pleuro-pneumonia were slaughtered in the United States, and every now and again cases have occurred in cargoes of animals landed in this country.

The theory that the case of the Deptford bullock was one of "corn stalk disease" is anything but a happy one in face of the description of the symptoms and of the post-mortem lesions given by writers on the subject. Thus, in the Journal of Comparative Medicine and Veterinary Archizes for February, Mr H. F. Spencer gives an account of the malady which shows that it is of the nature of a septic intoxication, and mentions that congestion of the lungs is found as one of the pathological phenomena.

But, allowing for a moment that the veterinary advisers of the Board of Agriculture and those who agreed with them were wrong in their diagnosis, it is quite evident that Professor Williams is not the man to convince the profession or the public of this. His last effort in this direction is the most remarkable of the whole series, for while, on the one hand, he asserts that the microscope is the final arbiter in the differentiation of broncho-pneumonia from pleuro-pneumonia, he, on the other hand, unhesitatingly pronounces that a given section of lung which has become mummified in the process of preservation is an example of broncho-pneumonia.

It will be acknowledged, I think, in face of the fact that out of 54,520 post-mortem examinations made by the veterinary officers of the Bureau of Animal Industry of America in I890, I,294 animals 
were found to be affected with pleuro-pneumonia, that the probabilities are in favour of its occasional existence amongst the thousands of animals landed at our ports from the United States; and further, that in view of this fact the opinion of Professor Williams is not likely to influence the powers that be in the course they think it necessary and wise to pursue with regard to the embargo at present laid on American cattle.

\section{EDITORIAL ARTICLES.}

\section{THE PREVALENCE OF TUBERCULOSIS AMONG CATTLE IN GREAT BRITAIN.}

WrAT proportion of cattle in this country are affected with tuberculosis? Prudence demands that some information on this head should be forthcoming before any hasty legislation is carried out either regarding the sale of tuberculous carcases or the seizure and slaughter of tuberculous animals. If there is to be wholesale or even partial seizure of tuberculous carcases, and if tuberculosis is to be enrolled as a contagious disease and have directed against it measures intended to stamp it out or repress it, it may be assumed that compensation will bc awarded wherever the carrying out of such measures interferes with private interests on public grounds. In reply to this it may be said that money considerations must not be allowed to stand in the way where human life and health are at stake, and that if the sale of tuberculous meat is fraught with danger to human beings it must be stopped at all costs. To the abstract principle here laid down one is almost bound to assent, but in actual practice money considerations cannot be left out of account. First and foremost the degree of danger must be weighed, and then against that the cost of carrying out the measures best fitted to reduce or altogether remove such danger. And even if it be contended that the cost, no matter how great, must be incurred, it is still desirable to forecast it, if that is possible.

This question was touched upon by Dr Burdon Sanderson in opening the discussion on Tuberculosis at the International Congress for Hygiene and Demography held in London in August last, and he quoted the estimate of M. Arloing, who calculates the proportion of tuberculous cattle (in France) to be 5 per rooo. M. Arloing's calculations were based upon the statistics furnished by the public abattoirs in France, but there is some reason for suspicion that they are not trustworthy even for that country, and, as will appear, they are most certainly not applicable to the case of some other States.

Professor Ostertag, who was for six years one of the chief inspectors at the Berlin slaughter-house, and whose authority on this matter will 